\title{
LASER TECHNOLOGIES - MASTER'S PROGRAM BETWEEN TWO EUROPEAN UNIVERSITIES OF APPLIED SCIENCES FROM LATVIA AND GERMANY
}

\author{
Aivars Vilkaste \\ Lyubomir Lazov \\ Hristina Deneva \\ Ērika Teirumnieka
}

\section{Edmunds Teirumnieks}

\author{
Pāvels Narica \\ Rezekne Academy of Technologies, Latvia
}

\begin{abstract}
Laser equipment and laser technologies are among the most modern, fastest growing and most promising branches of science and technology in the 21st century. The first laser was created in 1960 and for about 55 years, today there is hardly any area of our lives in which lasers and related technologies are not applied. Laser systems and related innovative technologies ensuring high precision, productivity and quality of production have been developed and proposed worldwide from hundreds of scientific research institutes and companies.

The Master's program is accredited in two European universities in Germany and Latvia and allows for the production of double diplomas. The course is based on international experience and reflects the most recent advances in laser techniques and technologies. The program examines the physical fundamentals and technical realization of various types of laser systems and their specific characteristics. First the necessary foundations of the laser physics, optics and the interaction of radiation with matter are presented, followed by more detailed examination of the problems of laser technology in various fields of science, technology and industrial production. Basic physical and technical solutions of the building blocks of lasers are presented in details, such as: optical resonators, active environments, excitation systems, management systems, laser generation. As well as specific issues and practical examples of industrial applications are described.
\end{abstract}

Keywords: laser, laser technologies, curriculum, Master's program, internationalization in Higher Education. 


\section{Introduction}

Today, along with nanotechnologies, the optical and laser technologies are crucial to the global progress of economy and society in $21^{\text {st }}$ century. Development and production of laser technologies in Europe (particularly in Germany and Latvia) is strategic priority [Hightech-Strategie 2020 für Deutschland, 2010]. Nowadays Germany is one of the global leaders in the field of optical technologies. Until 2020 more than 15 billion euros are expected to be invested in this sector of industry (BMBF - Initiative Photonic 2020) [BMBF, 2011].

During the last 15 years a range of areas has expanded enormously in which the "LASER" (Light Amplification of Stimulated Emission of Radiation) is used for industrial production. A number of sectors may be mentioned such as: mechanical engineering, precision engineering, food technologies, automotive industry, and aircraft construction, electronics, and microelectronics, etc., whose development is unimaginable in the field of technologies without using lasers. This is due to the unique advantages offered by laser as a processing tool:

- no tool wear,

- $\quad$ no exerting pressure on the material,

- possibility for machining of details with complex configuration,

- flexibility of the process - rapid implementation to new constructive solutions,

- low production costs and high productivity,

- high quality,

- $\quad$ small area of thermal effect,

- $\quad$ easy integration of laser source in the internal factory production lines,

- $\quad$ processing of metals, non-metals, alloys, semiconductors, etc.,

- environment-friendly technology, etc. [Poprawe, Boucke, \& Hoffman, 2017].

Classical training in mechanical engineering and electronics today is not sufficient to meet the needs of modern industrial production and there is increased requirement for training of interdisciplinary specialists to be able to solve innovative problems lying on the borders between several fields of sciences. To carry out work on the modern laser technologies a wide spectrum of knowledge is required from training modules such as electronics, electrical engineering, automation management, optics, and many other fields of the applied physics. Combination of various knowledge and competences is just an indispensable for the success of modern industrial production and development. 
Therefore the curriculum today must be written on modular principle and has to provide the opportunities mentioned above.

The Master's study program "Laser Technologies" is offered by the University of Applied Sciences (UAS) Mittweida, Germany, and the Rezekne Academy of Technologies (RTA), Latvia. The program was opened for studies in September 2015. Main goal of this study program is to prepare high level educated specialists in the field of lasers with strong emphasis on practical and scientific aspects of knowledge.

\section{What is proposed in the new Master's program?}

The program allows participation of students that graduated from Bachelor's degree, even of different specialties. This combination is knowingly encouraged because for engineering bachelors as well as for nature science, mathematical students it is particularly interesting to have opportunity to specialize and get additional knowledge in the field of contemporary optical and laser technologies. Forecasts and analyzes indicate that this tendency will continue increasing in Germany and the European Union over the coming years. It turns out that this new priority area of the $21^{\text {st }}$ century is important for our industrial and social development, is significant and attractive for the young people engaged with science and technologies [Photonik-Akademie BMBF, 2011].

The Master's program was developed under collaboration and integration of both universities with scientific and research centres - Laser Centre in Mittweida and RTA Physical processes and laser technologies research centre. This cooperation is providing an opportunity for linking educational process with the studies of scientists. Thus master's students get possibilities to connect their master's themes with the research necessary for business and economics of both countries, Germany and Latvia. Also it creates possibilities for invitation and integration of students in the scientific and team research while they are still studying and participating in scientific seminars, conferences, and other scientific forums.

\section{Two universities - one program - two diplomas}

International Master's programs enable participants during the course to study in two European countries or to study only in their own country: Latvia or Germany.

Advantages offered by the new program are as follows:

- International recognition of completed educational degree;

- Modular type of training allowing flexibility; 
- Transparency and equivalence of assessments obtained in the training based on the European system of credit transfer ECTS (European Credit Transfer System).

ECTS is based on fundamental principles such as: full awareness, mutual trust and agreement, taking into account the workload of students using of credits. Application of this system in the learning process to the Master's program is based on: full student lecture and outside lecture employment for any particular discipline; giving opportunity for students to select their study subject, learning forms, as well as forms of individual work; recognizing of individual study period held in the partnership's university or recognizing different specialties of both universities complying with all requirements of curriculum and educational - qualification degree of the "Laser Technologies" specialty.

$1^{\text {st }}$ option - two diplomas for Masters (MSc)

\begin{tabular}{|l|c|c|c|c|c|}
\hline & $1^{\text {st }}$ semester & $2^{\text {nd }}$ semester & $3^{\text {td }}$ semester & $4^{\text {th }}$ semester & Result \\
\hline study in RTA & $\begin{array}{l}\text { study in UAS } \\
\text { Mittweida }\end{array}$ & & & & $\begin{array}{l}\text { RTA } \\
\text { and } \\
\text { UAS } \\
\text { Mittweida } \\
\text { diploma }\end{array}$ \\
\hline
\end{tabular}

DE students

$2^{\text {nd }}$ option - one diploma for Masters (MSc)

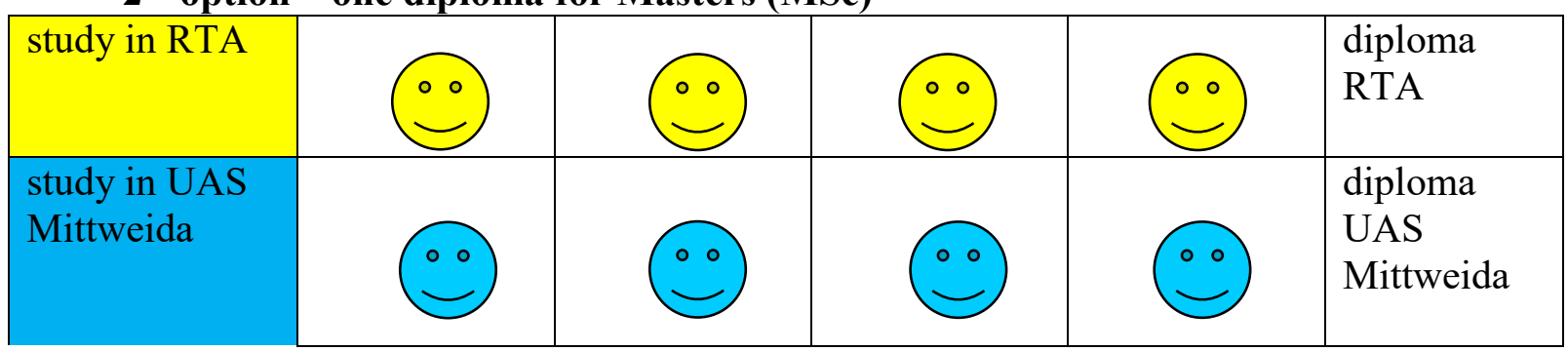

Figure 1 Two options to realization of the master's program

In the partner institution (figure1) a part of student's training may be carried out according to the program. The program is based on signed framework agreement between educational institutions and opens for the students a bilateral academic interchange for two semesters. This way the amount of academic time during the course of learning needed (4 semesters) suffices fulfilment of national requirements of both Latvia and Germany to receive two diplomas. It may be noted that both universities mutually recognize the acquired knowledge and evaluation, which is obtained in the course of 
studies in partner institution pursuant to a comparative evaluation table accepted and agreed between them. Modules developed in English allow to involve the students interested in the program from other European countries and to conduct partial training within Erasmus, as well as to invite professors and experts from leading companies in the industry for lecturing. Through realization of this opportunity, the idea of expanding the European student mobility is stimulated, which is found in general documents of the European Union (EU) for the field of education. This allows developing and deepening of the integration processes within the EU [Teichler, U., 2012].

\section{What modules are thought in the program and what is period of the training?}

The basic part of the Program during the first three semesters includes skills and knowledge for students according to the following basic modules:

- Solid-state physics, analytics (Festkörperphysik, Analytik),

- Quantum Mechanics, Statistical Physics (Quantenmechanik, Statistische Physik),

- Physical technologies (Physikalische Technologien),

- Modeling and simulation of physical processes (Modellierung und Simulation physikalischer Prozesse),

- Physical coating technologies (Physikalische Beschichtungstechnologien),

- Project management (Projektmanagement).

Special part of the Program offers obligatory and selectable modules such as:

- Laser-matter interaction (Laser-Materie Wechselwirkung),

- Laser equipment (Lasergerätetechnik),

- Components of laser technology (Komponenten der Lasertechnik),

- Micro- and nanotechnologies (Mikro- und Nanotechnologien),

- Current developments in laser technology (Aktuelle Entwicklungen der Lasertechnik),

- Optics design/microoptics (Optikdesign/Mikrooptik),

- Research and development module I and II (Forschungs- und Entwicklungsmodul I und II).

Training modules per semester and credits to the ETCS are shown in Table 1. 
Table 1 Training modules per semester and ETCS credits

\begin{tabular}{|c|c|c|c|c|}
\hline & 1. semester & 2. semester & 3. semester & 4. semester \\
\hline module1 & $\begin{array}{l}\text { Solid state physics } \\
-5 \text { credits }\end{array}$ & $\begin{array}{l}\text { Physical coating } \\
\text { technologies - } 5 \\
\text { credits }\end{array}$ & $\begin{array}{l}\text { Project } \\
\text { management - } 5 \\
\text { credits }\end{array}$ & \multirow{6}{*}{$\begin{array}{l}\text { Master thesis } \\
\text { and } \\
\text { colloquium - } \\
30 \text { credits }\end{array}$} \\
\hline module2 & $\begin{array}{l}\text { Quantum } \\
\text { mechanics - } 5 \\
\text { credits }\end{array}$ & $\begin{array}{l}\text { Physical analytics - } \\
5 \text { credits }\end{array}$ & $\begin{array}{l}\text { Optics design / } \\
\text { microoptics - } 5 \\
\text { credits }\end{array}$ & \\
\hline module3 & $\begin{array}{l}\text { Modeling and } \\
\text { simulation of } \\
\text { physical processes } \\
-5 \text { credits }\end{array}$ & $\begin{array}{l}\text { Laser-matter } \\
\text { interaction - } 5 \\
\text { credits }\end{array}$ & $\begin{array}{l}\text { Micro- and } \\
\text { nanotechnologies - } \\
5 \text { credits }\end{array}$ & \\
\hline module4 & $\begin{array}{l}\text { Laser equipment - } \\
5 \text { credits }\end{array}$ & $\begin{array}{l}1 \text { Elective Module - } \\
5 \text { credits }\end{array}$ & $\begin{array}{l}\text { Current } \\
\text { developments in } \\
\text { laser technology - } 5 \\
\text { credits }\end{array}$ & \\
\hline module5 & \multirow{2}{*}{$\begin{array}{l}2 \text { Electives } \\
\text { Module - } 10 \\
\text { credits }\end{array}$} & \multirow{2}{*}{$\begin{array}{l}\text { Research and } \\
\text { development } \\
\text { module I - } 10 \\
\text { credits }\end{array}$} & \multirow{2}{*}{$\begin{array}{l}\text { Research and } \\
\text { development } \\
\text { module II - } 10 \\
\text { credits }\end{array}$} & \\
\hline module6 & & & & \\
\hline credits & 30 & 30 & 30 & 30 \\
\hline
\end{tabular}

Latvian, German and English are one of the languages of study and the learning period is 4 semesters.

Content of the program provides to the participants key professional skills in the field "Laser technic and technologies" with possibility for their concrete realization not only at the national level, but also in the practice of the European common market.

After completion of the internationally recognized Master's program "Laser technologies" offering coupled degree diploma, undergraduate students have been professionally trained to work in wide range of professional areas:

- Optics and fine Mechanics;

- Automotive industry and Mechanical engineering;

- Aircraft construction and space equipment;

- Medical equipment;

- Measuring equipment;

- Optoelectronics and Semiconducting technics;

- Information and communication technology;

- Laser technology;

- Material treatment;

- Micro- and nanotechnologies;

- Biophotonics, etc. 
It is expected that optical technology will expand new market opportunities and offer new jobs, especially for the group of small and medium enterprises. For the last few years in Germany, which is the locomotive of optical technologies in Europe, more than 5,000 new jobs have been created. About $16 \%$ of them are in the business of processing industry (industry for processing of materials) [Baron, 2004; Kudic, M., 2011]. All of these may be in other EU countries as there is a need to have sufficient qualified staff being able to implement innovative solutions (know-how) in practice. A relatively new branch of optical and laser technologies lacks certain young trained professionals. That is why it is important to work actively in order to promote the knowledge in this area even in higher education institutions using the general public and businesses. Thus in the universities that offer such (like ours) curricula, it will increase interest and enhance the competition among candidates.

\section{Conclusion}

Engineering and technical staff and collaborators with their level of qualification have been crucial for the development of business innovations. This is true to a great extent (particular level) for companies that have selected the path of innovative optical and laser technologies.

Purposeful training and education of people that will respond to the market needs and the needs of industry is the right recipe (approach) for successful development and implementation of technical innovations. The rapid development of research in the field of optical technologies and laser technology has initiated creation of the Master's programs that would meet those needs.

German study "Optical Technologies in the $21^{\text {st }}$ Century" shows that recently there is an urgent deficiency of qualified personnel that can meet the needs of scientific research personnel being able to perform R\&D activities in this sector of the industry. Such assessments and analyzes come from a number of associations related to industry and business. Hence it constitutes an obstacle to development and application of optical and laser technologies within individual countries and generally the EU as well.

Development of scientific and innovation strategy in our globalizing world must include European and international dimensions in educational, research and technological policy of each EU country. Today more than ever it is clear that "Photonics" has been one of the most important elements of European research policy.

The European Technology Platform "Photonics $-21^{\text {st" }}$ includes more than 1600 partners and has developed an overall strategy of the European Union Member States in the field of optical and laser technologies [Butter, 2011; ETPP21, 2013; Poprawe, 2014]. Via the European Commission the "Optical and 
Laser Technologies" have been incorporated into the 5th "Key Enabling Technologies" important for Europe. The European Commission here perceives the most important technological potential for our economic development over the next 10 years. The created and accredited Master's program in both universities in Germany and Latvia is a good example for internationalization of this field of higher education.

\section{References}

Baron, \& Waldemar (2004). Impulse für Bildungsprozesse in den Optischen Technologien, Fachkräfte gewinnen - Zukunft sichern, LTJ Oktober 2004, Nr. 2, pp 30-34.

Bundesministerium für Bildung und Forschung (BMBF), Referat Photonik, Optische Technologien, Bonn, Berlin, 2011.

Butter, Maurits, etc. (2011). The Leverage Effect of Photonics Technologies: the European Perspective, Downloaded by http://www.photonics21.org/download/Leverage_ Internetversion.pdf

European Commission European credit transfer and accumulation system (ECTS) - Key features, Luxembourg: Office for Official Publications of the European Communities 2004, 9 pp., ISBN 92-894-4742-7.

European Technology Platform Photonics21, Towards 2020 - Photonics Driving Economy Growth In Europe, Multiannual Strategic Roadmap 2014-2020, Downloaded by http://www.photonics21.org/download/Brochures/Photonics_Roadmap_final_lowres.pd $\mathrm{f}$

Kudic, M., Guhr, K., Bullmer, I., \& Günther, J. (2011). Kooperationsintensität und Kooperationsförderung in der deutschen Laserindustrie, IWH, Wirtschaft im Wandel, Jg. 17 (3), 2011, S. 121-129.

Photonik-Akademie, Bundesministerium für Bildung und Forschung (BMBF) Referat 513 Photonik, Optische Technologien, Fraunhofer-Institut für Lasertechnik ILT, Bonn, Berlin, 2011.

Poprawe, R. (2014). Photonics in the $21^{\text {st }}$ century - the European technology platform photonics21, Fraunhofer ILT.

Poprawe, R., Boucke K., \& Hoffman D. (2017). Tailored Light 1: High Power Lasers for Production, Springer.

Teichler, U. (2012). International Student Mobility in Europe in the Context of the Bologna Process, Journal of International Education and Leadership, Volume 2, Issue 1 Spring 2012, pp 1-13. 